\title{
Effect of cadmium chloride on general body colouration and chromatophores of stinging cat fish, Heteropneustes fossilis (Bloch)
}

\section{Shareef Ahmad* \\ Department of Zoology, B.S.N.V.P.G. College Lucknow-226001 (U.P.) INDIA \\ Sandeep Shukla}

Department of Zoology, B.S.N.V.P.G. College Lucknow-226001 (U.P.) INDIA

Anand Mishra

Department of Zoology and Environmental Science, Gurukula Kangri Vishwavidyalaya Haridwar-249404 (Uttarakhand), INDIA

Deepak Kasherwani

Department of Zoology, University of Lucknow, Lucknow-226001 (U.P.) INDIA

Veena P. Swami

Department of Zoology, B.S.N.V.P.G. College Lucknow-226001 (U.P.) INDIA

Sanjive Shukla

Department of Zoology, B.S.N.V.P.G. College Lucknow-226001 (U.P.) INDIA

*Corresponding author. E-mail: meningitis111984@gmail.com

\begin{abstract}
Chromatophores, specialized pigment cells in poikilothermic animals, have shown great potential in their use as a cell-based biosensor in the detection of a broad range of environmental toxicants, as structure and number of chromatophores alters significantly under toxicant exposure. Skin coloration of Heteropneustes fossilis is due to melanin containing melanophores. Cadmium, the black listed and non essential heavy metal, is widely used that adversely affects vital activities of aquatic biota. $H$. fossilis, freshwater Indian stinging catfish, were subjected to exposure of 96 hour $\mathrm{LC}_{50}$ dose $(392.92 \mathrm{mg} / \mathrm{l})$ and $25 \%$ of 96 hour $\mathrm{LC}_{50}$ dose $(98.23 \mathrm{mg} / \mathrm{l})$ of cadmium chloride $\left(\mathrm{CdCl}_{2}\right)$ to evaluate toxic impact of cadmium on colouration and chromatophores. A significant decrease was observed in number of chromatophores after acute (highly significant $(F=70.50$; $\mathrm{P}<0.001)$ and sub acute (significant $(\mathrm{F}=0.29 ; \mathrm{P}<0.05)$ exposure along with heavy nacrotic, lytic and degenerative changes. Chromatophore gradually changed from reticulate to punctate-stellate and punctuate type as they lost their dendritic processes and aggregation of melanin towards centre. Most of the chromatophores lost their cellular entity due to degenerative changes and melanin was found dispersed in surrounding matrix. Peeling and fading of skin was the common feature in all exposure durations. Fish chromatophores may serve as better biomarkers in reference to metallic pollution and will also be helpful in accessing the health status of economically important fishes as well as worsening status of aquatic bodies.
\end{abstract}

Keywords: Cadmium chloride, Chromatophores, Heteropneustes fossilis, Histomorphology

\section{Article Info}

DOI: 10.31018/jans.v10i2.1758 Received: February 17, 2018 Revised: March 21, 2018 Accepted: April 24, 2018

\section{How to Cite}

Ahmad, S. et al. (2018). Effect of cadmium chloride on general body colouration and chromatophores of stinging cat fish, Heteropneustes fossilis (Bloch). Journal of Applied and Natural Science, 10(2): $655-660$

\section{INTRODUCTION}

Today, heavy metal contamination has become a major environmental issue and is one of the five major types of pollution commonly present in surface waters (Mason, 1996). They are natural components of the earth's crust and cannot be degraded or destroyed. The contamination of aquatic ecosystems with heavy metals through natural and anthropogenic sources is considered a major environmental concern due to their pervasiveness and persistence (Sanders, 1997). These heavy metals are well known for interfering biological activities of aquatic organisms including fishes
(Gupta et al., 2013; Hassan and Bakhiet, 2015; Srivastava et al., 2015; Mishra et al., 2016a; Mishra et al., 2016b; Dane and Sisman, 2017; Mustafa et al., 2017 and Nayar et al., 2017).

Pigmentation is a vital phenomenon of all organisms especially in poikilotherms, where it aid in visual communication, courtship, mimicry and survival (Fujii, 1993). Changes in pigmentation are either due to an increased number of chromatophore, an adaptive change over a period of days or weeks, or the movement of pigment organelles within chromatophore, eliciting an instantaneous change in colour intensity (Fujii, 1993; Sugimoto, 
2002).

Fish colour change is achieved by two major aspects, such as physiological and morphological colour change. Short-term physiological colour change in teleosts is caused by pigment aggregation/ dispersion in skin chromatophores in which the neuroendocrine and sympathetic nervous systems are involved (Fujii and Oshima, 1986; Fujii, 2000). In the long term, these systems also influence survival or apoptosis of the chromatophores and contribute to morphological colour change (Sugimoto, 2002).

Fish skin is highly sensitive to change in water quality and xenobiotic. Studies on fish skin shows that skin coloration gets changed very rapidly under metallic stress and any minute change in water quality or due to change in environmental conditions. Heteropneustes fossilis is a non scaly fresh water fish. Due to absence of scales, fish skin remains in direct contact of surrounding environment and is highly sensitive to xenobiotics (Rajan and Banerjee, 1991; Singh and Dutta Munshi, 1992; Chaudhry et al., 2001; Kasherwani et al., 2009; Dwivedi et al., 2017 and Madgulika and Arya, 2017) and environmental changes. Skin coloration of $H$. fossilis is due to melanin containing melanophores. Structure, type, distribution and number of chromatophores alter under toxicant exposure. These changes are also affected by toxicant concentration and exposure duration. Considering above facts, the present work was taken into consideration to evaluate effect of cadmium chloride $\left(\mathrm{CdCl}_{2}\right)$ on coloration and chromatophores of $H$. fossilis, a common cherished table fish of Indian sub continent, having high economical and ecological importance.

\section{MATERIALS AND METHODS}

The catfishes, $H$. fossilis (Bloch.) were collected from river Gomti and other water reservoirs in and around Lucknow, with the help of local fisherman and brought to the laboratory ( $\mathrm{N}-26^{\circ} 49, ; 5^{\prime} \mathrm{E}-80^{\circ}$ 55 ("58'in plastic containers under controlled temperature conditions. The healthy fishes (average length $15 \pm 1.5 \mathrm{~cm}$ and average weight $26.5 \pm 2.0 \mathrm{gm}$ ) were selected and sorted out for experimental purposes.

The freshly collected fishes were brought to laboratory and maintained in glass aquaria of 50 liter capacity in dechlorinated water at normal photoperiod. Prior to maintenance and acclimation, animals were treated with $0.2 \% \mathrm{KMnO}_{4}$ solution for 2 -3 minute to avoid the bacterial and viral infections and acclimatized to laboratory conditions according APHA et al., 1998, for15-20 days before commencement of experiment until fish starts normal feeding. Air pumps and stone diffusers were used in aquaria to maintain proper dissolve oxygen level of water. For cadmium chloride toxicity studies, short term (acute exposure) experiments were carried out on 96 hour $\mathrm{LC}_{50}$ dose $(392.92 \mathrm{mg} / \mathrm{l})$ and long term (sub acute exposure) experiment were carried out on $25 \%$ of 96 hour $\mathrm{LC}_{50}$ dose (98.23mg/l) of Cadmium chloride for $H$. fossilis and all the observations were taken after 24,48 , 72 and 96 hours exposure (for acute) and 10, 20 and 30 days exposure (for sub-acute) on live animal only. One aquaria having diluents water only served as control for each set. The physicochemical parameters of diluent water used in present experiment were as per Verma et al. (2010). For chromatophore number and morphology, skin pieces $(4 \times 4 \mathrm{~mm})$ were removed from the marked locations of the dorsal and lateral sides of the fish. The skin piece was fixed in alcoholic Bouin's fluid for 24 hours. After washing it with $70 \%$ alcohol, it was dehydrated in graded series of alcohols, cleared in xylene and mounted in Canada balsam. The structure of chromatophores was observed, under compound microscope and photographed using Canon A470 digital camera (super macro mode). Number of chromatophores was observed per microscopic field at 10X10 magnifications under compound microscope.

The replicates of the data obtained from different experiments for chromatophore count were compared with controls and statistically analyzed using test of significance (Student's t-test) on PC. The numerical data was analyzed using one way ANNOVA with statistical software package "MINITAB" on PC.

\section{RESULTS}

Numbers of chromatophores per microscopic field were found highly affected after Cadmium exposure of acute 96 hour $\mathrm{LC}_{50}$ dose $(392.92 \mathrm{mg} / \mathrm{l})$ and sub-acute $25 \%$ of 96 hour $\mathrm{LC}_{50}$ dose $(98.23 \mathrm{mg} / \mathrm{l})$. The change in chromatophores number are summaries in Table 1. A significant increase in chromatophore numbers was observed after 24 hour in comparison to control but gradually decreased significantly after 48 to 96 hour of exposure than control (Table 1). The difference between means of control and exposed animals were significant $(t$ $=3.15$; $P<0.05$ ) after 24 hour exposure and moderately significant $(\mathrm{t}=4.33 ; \mathrm{P}<0.01)$ after 48 hour exposure while highly significant $(\mathrm{t}=18.80$; $\mathrm{P}<0.001)$ after 72 hour and $(t=25.88 ; P<0.001)$ after 96 hour exposure. The overall variation in control group were insignificant $(F=4.40 ; P>0.05)$ where as highly significant $(F=70.50 ; P<0.001)$ in exposed group.

Same as acute exposure the chromatophore number/microscopic field was found greatly affected to $\mathrm{CdCl}_{2}$ exposure in comparing to controls. The alterations in chromatophore numbers are summarized in table 2. Gradual decrease in chromatophore numbers was observed in exposed animals $(110 \pm 2.88,95 \pm 2.88$ and $65 \pm 2.88)$ after 10, 20 and 30 day in comparison to controls ranging 
Ahmad S. et al. / J. Appl. \& Nat. Sci. 10 (2): 655 - 660 (2018)

Table 1. Effect of acute exposure of cadmium chloride on number of Chromatophores in $H$. fossilis.

\begin{tabular}{lll}
\hline \multirow{2}{*}{$\begin{array}{l}\text { Duration of } \\
\text { Exposure }\end{array}$} & \multicolumn{2}{l}{$\begin{array}{l}\text { Number of Chromatophores/ } \\
\text { microscopic field }\end{array}$} \\
\cline { 2 - 3 } & Control & Exposed \\
\hline 24 hour & $152.8 \pm 2.745$ & $163.8 \pm 2.154^{*}$ \\
48 hour & $153.2 \pm 4.726$ & $108.4 \pm 9.196^{* *}$ \\
72 hour & $160 \pm 2.236$ & $80 \pm 3.619^{* * *}$ \\
96 hour & $166.8 \pm 2.236$ & $60.8 \pm 3.441^{* * *}$ \\
\hline
\end{tabular}

Values are mean $\pm \mathrm{SE} ; \mathrm{N}=5 ;{ }^{*},{ }^{* *},{ }^{* * *}$ denotes differences in means to significant at $\mathrm{P}<0.05, \mathrm{P}<0.01$ and $P<0.001$ respectively.

from $138.33 \pm 4.40$ to $145 \pm 2.88$ up to 30 days.

The difference between mean of control and exposed animals were moderately significant $(\mathrm{t}=$ 5.38; $P<0.01)$ after 10 days exposure and $(t=$ 9.17; $P<0.01$ ) after 20 days exposure and highly significant $(t=19.60 ; P<0.001)$ after 30 days exposure. The overall variation were found insignificant $(F=0.76 ; P>0.05)$ in control group and statistically significant $(F=0.29 ; P<0.05)$ in exposed group.

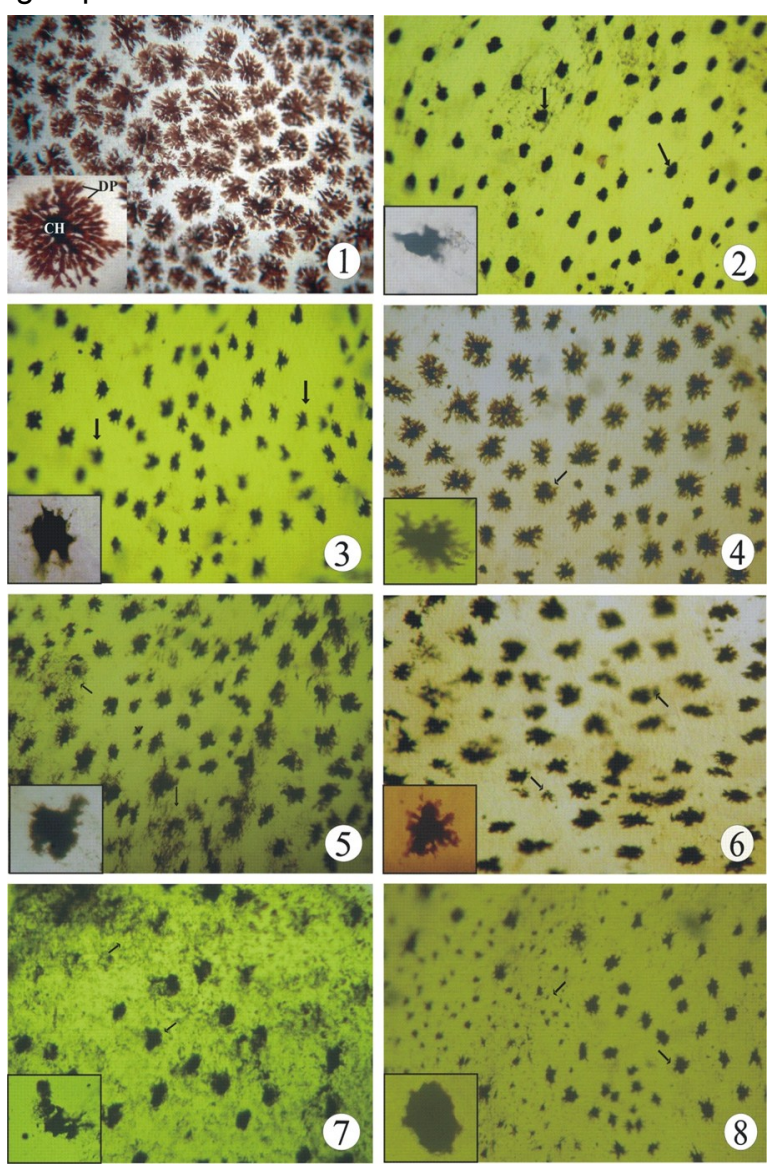

Plate 1. Explanation of figures (Figs. 1-8) Photomicrographs of Chromatophores of $\mathrm{H}$. fossilis after acute (Figs. 2, 4, 6 and 8) and sub acute (3, 5 and 7) exposure of $\mathrm{CdCl}_{2}$ : Fig. 1 Control; Figs. 2, 4, 6 and 8 (After 24, 48, 72 and 96hr respectively); Figs. 3, 5 and 7 (After 10, 20 and 30day respectively).
Table 2. Effect of sub acute exposure of cadmium chloride on number of chromatophores in $H$. fossilis.

\begin{tabular}{lll}
\hline \multirow{2}{*}{$\begin{array}{l}\text { Duration of } \\
\text { Exposure }\end{array}$} & \multicolumn{2}{l}{$\begin{array}{l}\text { No of Chromatophores/ } \\
\text { microscopic field }\end{array}$} \\
\cline { 2 - 3 } & Control & Exposed \\
\hline 10 Days & $138.33 \pm 4.409$ & $110 \pm 2.886^{* *}$ \\
20 Days & $143.33 \pm 4.409$ & $95 \pm 2.886^{* *}$ \\
30 Days & $145 \pm 2.887$ & $65 \pm 2.886^{* * *}$ \\
\hline
\end{tabular}

Values are mean $\pm \mathrm{SE} ; \mathrm{N}=5 ;{ }^{*},{ }^{* *},{ }^{* * *}$ denotes differences in means to significant at $\mathrm{P}<0.05, \mathrm{P}<0.01$ and $\mathrm{P}<0.001$ respectively.

$\mathrm{CdCl}_{2}$ imposed marked effect on the chromatophores morphology of $H$. fossilis after acute exposure. After 24 hour (Plate: 1 and fig. 2) chromatophore number was found slightly increased with reduced dendritic process and aggregation of melanin at the centre. About $80 \%$ melanophore were found in stello-punctate condition, at very few places breaking of the arms was noticed at this stage. After 48 hour (Plate 1 and fig. 4) the number of chromatophores was found slight decreasd than control, most of the chromatophores were in reticulate stellate condition. Leaving about $30 \%$ chromatophore in punctate condition. Melanin was found disperse in the dendritic process. After 72 hour (Plate: 1 and fig. 6) exposure number of chromatophore was found decreased and most of the chromatophores were found stellate condition. Degenerative changes were at certain places leaving broken part and melanin in the surround matrix. Melanin was found mainly concentrated in the centre but was also in some portion of dendritic process.

After 96 hour of exposure (Plate 1 and fig. 8) heavy necrotic, lytic and degenerative changes were found in chromatophores, broken chromatophores and melanin was found in the surroundings. Leaving very few reticulo-stellate and punctate types of chromatophores.

Sub acute exposure of $\mathrm{CdCl}_{2}$ imposed prominent changes in chromatophores of $H$. fossilis. After 10 days exposure number of chromatophores slightly decreased than control while distances between two chromatophores were increased (Plate 1 and fig. 3). Shape of the most of the chromatophore was change reticulate to stellatetype. Most of the dendritic process was found retracted and melanin pigment was found aggregated in centre.

After 20 days of exposure the number of chromatophore further decreased, shape of the most of the chromatophore was changed to punctate type, leaving $30 \%$ of chromatophores in stello-punctate condition (Plate 1 and fig. 5). The dendritic process was further reduced with aggregation of melanin at centre. Necrotic and degenerative changes were also noticed at very few places leaving melanin in the surrounding matrix.

After 30 day exposure the number of chromatophore and their size was found considerably reduced. Breaking of dendritic process as well as 
heavy destruction of chromatophore changes was noticed at this stage. Leaving most of the melanin pigment in surrounding matrix, very few chromatophores were noticed and most of them were in punctate condition (Plate 1 and fig. 7). Majority of the chromatophores were found with loss of cellular entity.

\section{DISCUSSION}

$H$. fossilis is a non-scaly air breathing catfish and its skin directly remains in contact of surrounding medium, also being directly exposed to the ambient toxicants, is used extensively as a potent indicator of contaminated aquatic environment (Rajan and Banerjee, 1991; Paul and Banerjee, 1996; Hemalatha and Banerjee, 1997 and Dwivedi et al., 2017).

Chromatophore cells located in the dermis are responsible for producing and altering an organism's overall pigmentation and colour intensity (Fujii, 1993). The processes of colour change are controlled by neuro-endocrine pathway or/and by cell itself. In both neural and hormonal regulation, the signals that trigger the reactions to generate efferent cues for the effector cells i.e., the chromatophores, either from the external environment or those from internal organs that do not influence the pigment cells directly, are processed in the CNS (Iwata and Fukuda, 1973; Fujii and Oshima, 1986; Baker, 1991; Fujii, 1993 and Gulzar et al., 2014). The pigment can be either dispersed throughout the cell, which gives a dark appearance, or it can be aggregated around the nucleus, which gives a pale appearance (Bagnara and Hadley, 1973; Fujii, 2000 and Aspengren et al., 2008). Chromatophore cells, a special class of pigment cells in cold blooded animals, have shown great potential in their use as a cell-based biosensor in the detection of a broad range of environmental toxicants (McFadden, 2002; Dierksen et al., 2004; Mojovic et al., 2004; Hutchison et al., 2008; Dukovcic, 2009; Dukovcic et al., 2010a; Dukovcic et al., 2010b and Roach, 2012). Chromatophore cells possess the motile pigment granules that intracellularly aggregate or disperse in response to external stimuli.

Major hormones involved are $\alpha-\mathrm{MSH}$ as a signal for dispersion, and $\mathrm{MCH}$ and melatonin as signals for aggregation (Fuji, 2000). Paracrine factors are also involved such as prostaglandins, opiates, endothelins and nitric oxide (Fuji 2000).

Rapid changes in body colour are dependent upon the motility of pigment organelles within chromatophore cells (Sugimoto, 2002). The pigment organelles disperse away from the nucleus of the cell to deepen body colour and aggregate toward the nucleus to pale body colour in response to external stimuli (Fujii, 1993 and Sugimoto, 2002). The size and density of chromatophores decreases as observed in acute and sub-acute exposure of present study may be due to gradual apoptosis which includes loss of cell activity, cell fragmentation and phagocytosis (Sugimoto et al., 2000), in later stages of sub-acute exposure. Cadmium may also exert direct cytotoxic effect on melanophores as observed in other metals like $\mathrm{Cu}, \mathrm{Hg}, \mathrm{Co}, \mathrm{Cr}$ etc (Rajan and Banerjee, 1991 on $H$. fossilis; Banerjee and Mukharjee, 1994 on $H$. fossilis and Radhakrishnan et al., 2000 on Channa striatus and Dwivedi et al., 2017).

Apart from the toxicity, several environmental factors such as light, water quality, temperature, salinity and chemicals/pollutants are also known to affect colour change in fishes and other animals (Fujii, 1969; Watanabe et al., 1965; Tripathi et al., 2005 and Pradeep et al., 2007). The changes observed after acute and sub-acute exposure of $\mathrm{Cd}$ may be due to its direct effect on nervous system and endocrine system of the fish. It is evident from present study that Cadmium imposes direct cytotoxic effect on melanophores that causes reduction in number of chromatophores, affecting colouration which in turn may affect various behavioural and physiological processes affecting survival of these economically $H$. fossilis.

\section{Conclusion}

Cadmium chloride was found to be highly toxic to the catfish $H$. fossilis. Significant $(P<0.001)$ decrease in number of chromatophores as well as marked cytological changes like chromatophores lost their cellular entity due to degenerative changes and melanin was found dispersed in surrounding matrix, peeling and fading of skin was the common feature in all exposure durations were noticed after Cadmium chloride exposure (acute $96 \mathrm{hr} 392.92 \mathrm{mg} / \mathrm{l}$ and sub-acute 30 days $98.23 \mathrm{mg} / \mathrm{l})$. Chromatophores can serve as better bio-marker of metallic pollution. After proper standardization, chromatophores number and morphology may be used in accessing the health status of economically important fish as well as worsening status of aquatic bodies.

\section{ACKNOWLEDGEMENTS}

Authors are thankful to the Dr. U.D. Sharma, Retd. Professor, Department of Zoology, University of Lucknow, Lucknow for valuable suggestions and supervision and also thankful to Principal, B.S.N.V.P.G. College, Lucknow (U.P.) India for providing necessary lab facilities.

\section{REFERENCES}

Aspengren, S., Hedberg, D., Sköld, H.N. and Wallin, M. (2008). New insights into melanosome transport in vertebrate pigment cells. Inter. Review of Cell and Molecular Biology, 245-302.

Bagnara, J.T. and Hadley, M.E., (1973). Chromatophores and color change: the comparative physiology of animal pigmentation. Prentice-Hall Englewood 
Cliffs, NJ.

Baker, B. I. (1991). Melanin-concentrating hormone: A general vertebrate neuropeptide. Int. Rev. Cytol. 126:1-47.

Banerjee, T.K. and D. Mukherjee (1994). Melanophore indexing: a quick bio-assay technique for detection of heavy metal toxicity. Curr. Sci. 6: 177-182.

Chaudhary, U. S., Rathod, V. and Vankhede, G.N. (2001). Effects of water extract of the bark Buchanania lanzan Linn. on behaviour and chromatophores of a fresh water fish, Labeo rohita. J. Environ Biol. 22: 229-231.

Dane, H. and Sisman, T. (2017). A histopathological study on the freshwater fish species chub (Squalius cephalus) in the Karasu River, Turkey. Turk. J. Zool., 41: 1-11.

Dierksen, K.P., Mojovic, L., Caldwell, B.A., Preston, R.R., Upson, R. and Lawrence, J. (2004). Responses of fish chromatophore-based cytosensor to a broad range of biological agents. J. Appl. Toxicol., 24: 363369.

Dukovcic SR. (2009). Ph.D. thesis. Oregon State University, Corvallis, OR. Chromatophores as cellbased biosensors for the detection of chemically and biologically toxic substances.

Dukovcic, S.R., Hutchison, J.R. and Trempy, J.E. (2010a). Conservation of the chromatophore pigment response. J. Appl. Toxicol., 30: 574-581.

Dukovcic, S.R., Hutchison, J.R. and Trempy, J.E. (2010b). Potential of the melanophore pigment response for detection of bacterial toxicity. Appl. Environ. Microbiol., 76: 8243-8246.

Dwivedi, B., Banerjee, S. and Vyas, R. (2017). Monitoring of sublethal effects of chromium on melanophores. Flora and Fauna, 23(2): 363-366.

Fujii, R. (1969a). Chromatophores and pigments. pp. 307-338. In Hoar WS, Randall DJ, (ed.), Fish Physiology, Volume III: Reproduction and Growth, Bioluminescence, Pigments, and Poisons. Academic Press, New York, NY.

Fujii, R. (1969b). Chromatophores and pigments. In Fish physiology (Eds: W. S. Hora and D. J. Rendall). Academic Press., 3: 307.

Fujii, R. (1993). Cytophysiology of fish chromatophores. Int. Rev. Cytol., 143: 191-255.

Fujii, R. (2000). The regulation of motile activity in fish chromatophores. Pigment Cell Res. 13: 300-319.

Fujii, R. and Oshima, N. (1986). Con- trol of chromatophore movements in teleost fishes. Zool. Sci., 3:13-47

Grandjean, P., White, R.F., Nielsen, A., Cleary, D. and de Oliveira Santos, E.C. (1999). Environ. Health Perspect. Methylmercury neurotoxicity in Amazonian children downstream from gold mining. 107: 587-591.

Gulzar R., Yaqoob, A. and Jain, A.K. (2014). Rate of color change in the skin of common carp, Cyprinus carpio As A Background Adaptation. New York Sci.J., 7(10): 91-96.

Gupta; K., Sachar, A. and Raina, S. (2013). Haematological Response of Freshwater Fish Puntius sophore (HAM.) to Copper Exposure. Int. J. Sci. Res. Pub., 3(5): 1-6.

Hassan, H. and Bakhiet, A. (2015). Bioaccumulation and histopathological alterations of heavy metals in the liver and kidney of Oreochromis niloticus fish collected from the blue Nile. Agricul. Biol. Sci. J. 1(5): 224-228.

Hemalatha, S. and T.K. Banerjee (1997). Estimation of sublethal toxicity of zinc chloride by histopathological analysis of fish (Heteropneustes fossilis, Bloch.) epidemis. Curr. Sci., 73: 614- 621.

Hutchison, J.R., Dukovcic, S.R., Dierksen, K.P., Carlyle, C.A., Caldwell, B.A. and Trempy J.E. (2008). Erythrophore cell response to food-associated pathogenic bacteria: implications for detection. Microb. Biotechnol., 1: 425-431.

Iwata, K.S. and Fukuda, H. (1973). Central control of colour changes in fish. In Chavin, W. (Ed) Responses of fish to Environmental changes. Spring field, Thomas. 316-341.

Kasherwani, D., Lodhi, H.S., Tiwari, K.J., Shukla, S. and Sharma, U.D. (2009). Cadmium Toxicity to Freshwater Catfish, Heteropneustes fossilis (Bloch). Asian J. Exp. Sci., 23(1): 149-156.

Madhulekha and Arya, S. (2017). Cadmium toxicity induced morphological alterations in indigenous fish, Heteropneustes fossilis (Bloch). Green chemis. and Techno. Lette., 3(1): 21-25.

Mason, C.F. (1996). Biology of fresh water pollution, third edition, Long Man U.K. PP : 1-4.

Mc Fadden P. (2002). Broadband Biodetection: Holmes on a Chip. Science. 297: 2075-2076.

Mishra, A., Shukla, S. and Chopra, A.K. (2016a). Acute toxicity of copper sulphate and potassium chromate to "tailless freshwater flea", Simocephalus vetulus (Crustacea-Cladocera). Inter. J. Adv. Res., 4(6): 316321.

Mishra, A., Shukla, S. and Chopra, A.K. (2016b). Physiological responses of heart of tailless fresh water flea Simocephalus vetulus (Crustacea-cladocera) under copper sulphate stress). CIBTech J. Zool., 5(3): 5259.Mizusawa, K., Kobayashi, Y., Sunuma, T., Asahida, T., Saito, Y., and Takahashi, A. (2011). Inhibiting roles of melanin-concentrating hormone for skin pigment dispersion in bar fin flounder, Veraspermoseri. Gen.Comp.Endocrinol., 171: 75-81.

Mojovic L, Dierksen KP, Upson RH, Caldwell BA, Lawernce JR, Trempy J.E. (2004). Blind and naïve classification of toxicity by fish chromatophores. J. Appl. Toxicol., 24: 355-361.

Mustafa S.A., Al-Faragi J.K., Salman N.M. and AlRudainy A.J. (2017). Histopathological alterations in gills, liver and kidney of common carp, Cyprinus carpio exposed to lead Acetate. Adv. Anim. Vet. Sci., 5 (9): 371-376.

Nayar, B., Mukati, K. and Bhattacharya, L. (2017). Effect of Cadmium chloride on histoarchitecture of inter renal and chromaffin cells of fresh water fish Heteropneustes fossilis and recovery of damaged tissue by herbal compound Ashwagandha. Int. J. Life Sci. Scienti. Res., 3(4): 1190-1199.

Paul, V.I. and T.K. Banerjee (1996). Analysis of ammonium sulphate toxicity in the catfish Heteropneustes fossilis using mucocyte indexing. Pol. Arch. Hydrobiol., 43: 111-125.

Pradeep K, Sheikh, I A., Aherwar, M and Ovais, M (2007). Methyl parathion induced effects on the Oreochromis mossambica (Peters) Melanophores in vitro. J. of Herbal Medicine and Toxicology., 1(2): 4954.

Radhakrishnan, M.V., Hemalatha S. and Paul V.I. (2000). Effect of cadmium chloride on the melanophores of Channa striatus (Bloch). Indian J. Fish., 47 (2): 135-141.

Rajan, M.T. and T.K. Banerjee (1991). Histopathological 
Ahmad S. et al. / J. Appl. \& Nat. Sci. 10 (2): 655 - 660 (2018)

changes induced by acute toxicity of mercuric chloride on the epidermis of freshwater catfish Heteropneustes fossilis (Bloch.). Ecotoxicol. Environ. Safe., 22: 139-152.

Rajan, M.T. and T.K. Banerjee (1991). Histopathological changes induced by acute toxicity of mercuric chloride on the epidermis of freshwater catfish Heteropneustes fossilis (Bloch.). Ecotoxicol. Environ. Safe., 22: $139-152$.

Sanders, M.J. (1997). A field evaluation of the freshwater river crab, Potamonan tes warren, as a bio accumulation indictor of metal pollution. Thesis, Ran Afrikaans University, South Affrica.

Singh M., Ansri, A.A., Muller, G. and Singh I.B. (1997). Heavy metal in freshly deposited sediments of the Gomti river (a tributary of the Ganga river): Effects on human activities. Environ. Geology. 29(3-4):252-264.

Singh, A. and Dutta Munsi, J.S. (1992). Effect of sublethal mercuric chloride exposure on melanophores of a catfish, Heteropneustes fossilis (Bloch). J. Environ. Biol., 13(4): 303-304.
Srivastava, A., Singh, S. and Tanuallen (2015). Comparative toxicity of arsenic and cadmium combined metal toxicity in fresh water fish with Yamuna water fish. Int. J. Pharm. Bio. Sci., 6(4): 1019-1032.

Sugimoto, M. (2002). Morphological color changes in fish: regulation of pigment cell density and morphology. Microsc. Res. Tech., 58: 496-503.

Takahashi, A., and Kawauchi, H. (2006a). Evolution of melanocortin systems in fish. Gen.Comp. Endocrinol., 148: 85-94.

Tripathi, M., Tripathi, A. and Gopal, K. (2005). Impact of fluoride on pigmentation of a fresh water fish, Channa punctatus. J. of Applied. Bio. Sci., 31(1): 35-38.

Trivedi. R.K. (2001). Aquatic Pollution and Toxicology, first edition A.B.D. Publisher.

Verma, D.R., Lodhi, H.S., Tiwari, K.J., Shukla, S. and Sharma, U.D. (2010). Copper sulphate induced changes in scaphognathite oscillations and oxygen consumption of fresh water prawn, Macrobrachium lamarrei (Crustacea Decapoda). J. of Appl. and Nat. Sci., 2(1): 34-37. 